\title{
The current and potential contribution of home-grown vegetables to diets in South Africa\#
}

\author{
EMW Maunder* and JL Meaker \\ University of KwaZulu-Natal, Discipline of Dietetics and Human Nutrition, School of Agricultural Sciences and Agribusiness, \\ Private Bag X01, Scottsville, Pietermaritzburg 3201, South Africa
}

\begin{abstract}
In this paper the current and potential utilisation of crops (bought and home produce) in diets in South Africa is reviewed. Available data shows that at all levels, national, household and individual, the amounts of fruits and vegetables available and consumed are about half the WHO (2003) recommendations of at least $400 \mathrm{~g}$ per day. To counteract this, the South African Food Based Dietary Guidelines promote fruit and vegetable consumption.

The 1999 National Food Consumption Survey (NFCS), showed that in South Africa, nationally, 17\% of the sample produced crops only, 9\% produced crops and livestock and $8 \%$ produced livestock only. Median intakes of nutrients such as energy, vitamin A and calcium for children in rural households with crop and livestock production, although raised, were still below requirements. However, evaluation of an intervention which combined production of vitamin A rich crops in home gardens with nutrition education and growth monitoring, showed vitamin A intakes increased above required levels. Another possible approach is the promotion of the consumption of indigenous vegetables, which are rich sources of several micronutrients. The 1999 NFCS data showed that ten percent of the children in rural areas consumed wild leaves/spinach.

In conclusion, the traditions of crop production and indigenous vegetable consumption can be built on, by the combined efforts of agriculturalists and nutritionists. The increased utilisation of indigenous crops in the South African diet would contribute to combating both under-nutrition and over-nutrition.
\end{abstract}

Keywords: home gardens, home produce, crop production, indigenous vegetables, nutrition

\section{Introduction}

This paper focuses on the current and potential utilisation of crops (bought and home produce) in diets in South Africa. South Africa, in common with other middle income developing countries (Steyn et al., 2006a), has a double burden with regards to nutrition, i.e. both under-nutrition and over-nutrition. Both have negative implications for health.

It was estimated (based on food poverty and inadequate energy availability using data from the 1995 National Income and Expenditure Survey) that 51.5\% of households in South Africa were food insecure in 1995 (Rose and Charlton 2002). Fifty two percent (52\%) of households were considered "hungry" (based on a subjective questionnaire on perceptions of hunger), and $23 \%$ of households were classified as being at 'risk of hunger' in the 1999 National Food Consumption Survey of children aged 1-9 years (Gericke et al., 2000). National nutrition surveys have only been possible since the formation of a democratic South Africa in 1994, and to date only two national nutrition surveys have been carried out, for which there are data available. The South African Vitamin A Consultative Group (SAVACG) study of children aged six months to six years old (Labadarios and Van Middelkoop, 1995) found problems of stunting in 23\% of children, underweight in 9\%, marginal vitamin A status in 33\% and anaemia in 21\%. The 1999 National Food Consump-

\footnotetext{
Revised version. Originally presented at the International Symposium on the Nutritional Value and Water Use of Indigenous Crops for Improved Livelihoods held on 19 and 20 September 2006 at the University of Pretoria in Pretoria, South Africa

* To whom all correspondence should be addressed.

푤 +2733 260-5453; fax: +273 260-6270; e-mail: maundere@ukzn.ac.za
}

tion Survey (NFCS) of households with children aged 1-9 years (Labadarios et al., 2005) showed that dietary intakes of energy and a large number of micronutrients are low in South African children aged 1 to 9 .

At the same time there is evidence of overweight and obesity in South Africa. Data from the 1999 NFCS also shows that $17 \%$ of the children were overweight and obese (Steyn et al., 2005). Information from the 2003 Demographic and Health Survey (Department of Health, 2004) shows that in adults the prevalence of obesity was very high, especially in women, where it ranged from 11 to $41 \%$ for different age groups. Underweight prevalence in adults is much lower than overweight prevalence, viz. $12.4 \%$ for men and 6\% for women (Department of Health, 2004). Obesity and overweight are found also in low income households. There is convincing evidence linking overweight and obesity with chronic diseases of lifestyle, including Type 2 diabetes mellitus, cardiovascular disease and cancer (WHO, 2003).

In this review of the current and potential utilisation of crops (bought and home produce) in diets in South Africa the South African Food Based Dietary Guidelines are firstly discussed. Current information available on the South Africa diet with particular reference to vegetables and fruits are presented. This is followed by an examination of nutrient intakes of children aged 1 to 3 years in homes with crop production, livestock production and non producers. A successful South African intervention to improve production of vitamin A rich crops and nutrient intakes is discussed. Finally, the potential utilisation of indigenous crops in the diets of South Africans is discussed.

\section{South African food-based dietary guidelines}

South Africa has developed its own Food-Based Dietary Guidelines (FBDG) in response to the FAO/WHO initiative to 
substantially reduce malnutrition, micronutrient malnutrition and diet-related communicable and non-communicable disease. Food-Based Dietary Guidelines are based on the concept that nutrition education should be focused on foods rather than nutrients, particularly foods which are locally available. The South African FBDG were developed based on an analysis of the dietary habits of South Africans, their nutritional status and the disease patterns in South Africa. The South African FBDG aimed to address both over- and under- nutrition and to provide nutrition education for all populations and sectors of South African society (Vorster et al., 2001).

In total eleven guidelines were formulated for South Africans over the age of 7 years. The two guidelines which are of particular interest in relation to this paper are 'Enjoy a variety of foods' and 'Eat plenty of vegetables and fruit every day'. The scientific rationale for these guidelines included the importance of an adequate micronutrient intake and the observed inverse relationships which have been shown between high dietary variety and vegetable and fruit consumption and mortality (all causes, cancer and cardiovascular disease) (Maunder et al., 2001; Love and Sayed, 2001). This is in line with the 2003 WHO report 'Diet, Nutrition and the Prevention of Chronic Diseases'. The expert analysis of available data concluded that increased fruit and vegetable consumption decreases the risk of obesity and cardiovascular disease (convincing evidence), and decreases the risk of type 2 diabetes and cancer (probable evidence). The advice of this report (WHO, 2003) was that at least $400 \mathrm{~g}$ of fruit and vegetables should be eaten daily.

In discussing the South African FBDG in an editorial, Labadarios and Steyn (2001) suggested that indigenous vegetables should be promoted, particularly as a culturally appropriate and affordable alternative to fruit. In particular, Labadarios and Steyn (2001) say 'one should guard against the exclusive promotion of "exotic" fruits and vegetables, which could result in indigenous plants and their produce being regarded as inferior, even when many are nutritionally superior.'

\section{South African diets with particular reference to vegetables and fruits}

National data from the Food and Agricultural Organisation Statistics (FAOSTAT) for South Africa shows that $42 \mathrm{~kg}$ of vegetables per capita per year (115 g/person.d) and $33 \mathrm{~kg}$ of fruit (91 g/person·d) are supplied at the national level (Keller, 2005).

Analysis of household availability of different foods, from the 1995 Income and Expenditure Survey Data (Rose et al., 2002) showed that $196 \mathrm{~g}$ of vegetables and fruits were available per person per day at the household level, which is similar to the figure obtained from the national data. This differed between rural and urban settings (141 and $256 \mathrm{~g} /$ person-d respectively).

The 1995 and 2000 Income and Expenditure Surveys in South Africa showed that the highest proportion of household expenditure goes towards buying food (20\% in 1995 and 22\% in 2000). Ten percent of the expenditure on food was on vegetables and $5 \%$ on fruit and nuts. The proportion of the total household income which is spent on food is particularly high for the poorest in the country (50\% in 1995 and 57\% in 2000) but is low in terms of actual amount of money spent on food for the year (R2 800 in 1995 and R2 400 in 2000; adjusted for inflation to 2000 prices) (Hirschowitz, 2002). Thus the low consumption of vegetables and fruits is not surprising.

At the individual level, mean intakes by children aged 1 to 5 and 6 to 9 years were shown to be 52 and $58 \mathrm{~g}$ respectively per person per day for vegetables and 48 and 60 g respectively per person per day for fruit (Steyn et al., 2003), using data from the 1999 NFCS. There are no national food consumption data for adults, but Steyn et al. (2003), analysed some ad hoc studies of adults and showed that vegetable intake was 91 to $93 \mathrm{~g} /$ person.d and fruit intake 62 to $103 \mathrm{~g} /$ person·d. The 1999 NFCS showed that there were few types of food available in many of the households of these children. For households where the annual income was less than R12 000, the mean number of different foods found in the household was eight (Maunder and Labadarios, 2000). Most of the households had maize and sugar in the house, and most of the children consumed these two food items, but few other foods were present. Thus at all levels, national, household and individual, the amounts of fruits and vegetables available and consumed are much lower than the WHO (2003) recommendations of at least $400 \mathrm{~g} / \mathrm{d}$. In addition there are severe financial limitations to increased consumption for many.

\section{Comparison of nutrient intakes in households with and without crop production}

The interventions suggested by nutritionists to combat low nutritional intakes, include nutrient supplementation, food fortification and dietary diversification. One means of dietary diversification often suggested, is that of home agricultural production, including home gardens. Given the low incomes and low expenditure on food, this would seem a very useful route to explore in South Africa. The data set provided by the NFCS gave us the opportunity to compare households with and without agricultural production. Comparisons were made between nutrient and food intakes in children aged 1 to 3 years of age. Given that levels of home agricultural production may differ in rural and urban areas, this was examined in rural and urban areas (Bolaane, 2006).

Nationally $17 \%$ of the sample produced crops only, $9 \%$ produced crops and livestock and $8 \%$ produced livestock only. The crops only group, were located fairly evenly across the rural (54.5\%) and urban areas (45.5\%). However, the crops and livestock group and the livestock only group were located predominantly in the rural areas (89.1\% and $89.2 \%$ respectively).

This analysis showed that in the rural areas intakes of several nutrients (energy, Vitamin $\mathrm{A}$, folate, vitamin $\mathrm{B}_{6}$, vitamin $\mathrm{C}$, calcium and iron) differed significantly between the groups and were higher in groups with own production (Table 1). However, median intakes were still found to be below the Estimated Average Requirements (EAR). For urban areas energy, vitamin $\mathrm{A}$, vitamin $\mathrm{C}$ and calcium intakes were increased in children in households in the crop producing group, compared to intakes in the non-producing households (Bolaane, 2006). Although this initial comparison showed some increase in the intakes of some nutrients by agricultural producers, in order to achieve adequate intakes more needs to be done.

\section{South African interventions to improve nutrient intakes through crop production}

There have been studies in South Africa which have investigated nutrient intakes in households with gardens as interventions to improve nutrient intakes. There has been some controversy in the South African literature with some authors (Webb, 2000; Schmidt and Vorster, 1995) questioning the impact of gardens on nutrient intake. However, Faber et al. (2002) found in an experimental study that home gardens, together with nutrition education and growth monitoring, led to increased vitamin $\mathrm{A}$, riboflavin, vitamin $\mathrm{B} 6$, and vitamin $\mathrm{C}$ intakes in children in the 


\begin{tabular}{|c|c|c|c|c|c|c|c|c|c|c|}
\hline \multicolumn{11}{|c|}{$\begin{array}{l}\text { TABLE } 1 \\
\text { Comparison of nutrient intakes of children aged 1-3 years from households producing crops and/or livestock } \\
\text { in rural South Africa, measured by 24-hour recall (after Bolaane, 2006) }\end{array}$} \\
\hline \multirow[t]{3}{*}{ Nutrient } & \multirow[t]{3}{*}{ EAR $^{1}$} & \multirow{2}{*}{\multicolumn{2}{|c|}{$\begin{array}{c}\text { Crops only } \\
(n=115) \\
\end{array}$}} & \multirow{2}{*}{\multicolumn{2}{|c|}{$\begin{array}{c}\text { Crops and livestock } \\
(\mathrm{n}=98) \\
\end{array}$}} & \multirow{2}{*}{\multicolumn{2}{|c|}{\begin{tabular}{c|} 
Livestock only \\
$(\mathrm{n}=\mathbf{8 2})$ \\
\end{tabular}}} & \multirow{2}{*}{\multicolumn{2}{|c|}{$\begin{array}{c}\text { Non-producers } \\
(\mathrm{n}=286)\end{array}$}} & \multirow[t]{3}{*}{ P-Value ${ }^{5}$} \\
\hline & & & & & & & & & & \\
\hline & & Median & Q1 - Q3 ${ }^{4}$ & Median & Q1 - Q3 ${ }^{4}$ & Median & Q1 - Q3 ${ }^{4}$ & Median & Q1 - Q3 ${ }^{4}$ & \\
\hline Energy $(\mathrm{kJ})$ & $4280^{2}$ & 3915.9 & 2945.0- 5437.0 & 4185.8 & 3090.6- 5506.9 & 3703.7 & $2881.6-4734.5$ & 3404.8 & 2626.9- 4504.7 & $<0.0001$ \\
\hline Protein (g) & 11.5 & 26.7 & $18.1-39.6$ & 26.5 & $18.1-35.9$ & 25.2 & $16.7-38.6$ & 24.6 & $17.4-37.1$ & 0.7581 \\
\hline Vitamin A (RE) & 210 & 188.1 & $61.1-419.0$ & 164.8 & $67.6-400.0$ & 156.8 & $50.8-302.5$ & 110 & $49.5-260.2$ & 0.0056 \\
\hline Thiamin (mg) & 0.4 & 0.6 & $0.40-0.80$ & 0.58 & $0.44-0.77$ & 0.56 & $0.40-0.71$ & 0.49 & $0.35-0.66$ & 0.2715 \\
\hline Riboflavin (mg) & 0.4 & 0.32 & $0.17-0.59$ & 0.43 & $0.19-0.70$ & 0.35 & $0.22-0.68$ & 0.36 & $0.20-0.62$ & 0.3515 \\
\hline Niacin (NE) & 5.0 & 3.8 & $2.5-6.1$ & 3.7 & $2.3-5.9$ & 3.1 & $2.1-5.7$ & 3.7 & $2.2-6.7$ & 0.5772 \\
\hline Folate $(\mu \mathrm{g})$ & 120 & 70.5 & $36.9-123.8$ & 84.9 & 49.3-154.5 & 56.8 & $35.1-98.5$ & 58.9 & $38.3-92.8$ & 0.0009 \\
\hline Vitamin $B_{6}(\mathrm{mg})$ & 0.4 & 0.35 & $0.24-0.57$ & 0.43 & 0.26-0.59 & 0.32 & $0.19-0.53$ & 0.31 & $0.20-0.49$ & 0.0005 \\
\hline Vitamin $_{12}(\mu \mathrm{g})$ & 0.7 & 0.27 & $0.00-1.17$ & 0.41 & $0.00-1.40$ & 0.56 & $0.00-2.00$ & 0.64 & $0.08-1.50$ & 0.0372 \\
\hline Vitamin C (mg) & 13 & 13.2 & $3.0-31.1$ & 9.9 & $3.5-25.5$ & 12.5 & $4.1-23.9$ & 8.4 & $2.0-21.8$ & 0.0483 \\
\hline Calcium (mg) & $500^{3}$ & 245.2 & $95.8-461.4$ & 249.5 & $96.1-458.6$ & 224.4 & $105.4-426.8$ & 202.8 & $87.2-349.7$ & 0.032 \\
\hline Iron (mg) & 3.0 & 4.2 & $2.6-6.6$ & 3.8 & $2.7-6.4$ & 4 & $2.1-6.6$ & 3.6 & $2.3-5.8$ & 0.0365 \\
\hline Zinc (mg) & 2.2 & 3.7 & $2.5-5.4$ & 3.5 & $2.6-5.1$ & 3.3 & $2.0-5.2$ & 3.2 & $2.3-4.7$ & 0.3206 \\
\hline
\end{tabular}

1 Institute of Medicine 2002, 2001, 2000, 1998, 1997

Estimated energy requirement for children aged 1-2 years

Adequate intake

Q1-Q3 = interquartile

Kruskal-Wallis Test comparing the four test groups

experimental group, compared to the nutrient intakes of children in control group. In this study the households in the project group had gardens producing $\beta$-carotene rich fruits and vegetables. Baseline median vitamin A intakes of children aged 2-5 years were $150 \mathrm{RE}$ per day, similar to those found in the 1999 NFCS (Steyn and Labadarios, 2000; MacIntyre and Labadarios, 2000), and the median intakes of vitamin A in the project group were raised to $1133 \mathrm{RE}$ per day which is well above the requirement of 400RE per day (RDA) or 210RE (EAR).

\section{Indigenous crops in the South African diet}

The diets of children in South Africa consist mainly of staple plant foods and lack dietary diversity, which results in micronutrient deficiencies (Labadarios et al., 2005). There is potential to improve micronutrient intake by increasing the consumption of indigenous crops (Modi et al., 2006; Chadha and Oluoch, 2002; Nesamvuni et al., 2001).

Indigenous plants occur naturally in an area. Indigenous crops/vegetables are usually adapted to harsh environments and generally require simpler technologies and inputs to grow and can therefore be cultivated in more arid regions (Van der Walt et al., 2005; Jansen van Rensburg et al., 2004; Chadha and Oluoch, 2002). Green, leafy vegetables, referred to as imifino, morogo or miroho in different indigenous South African languages, are sometimes defined as "a local term for a collection of wild-growing dark-green leafy vegetables resembling spinach" (Faber et al., 2002; Nesamvuni et al., 2001). However, imifino is actually a collective term for various dark-green leaves that are eaten as a vegetable, irrespective of whether the leaves grow wild or come from vegetables such as pumpkin, beetroot and sweet potato (Faber et al., 2007).

The South African Food Composition Tables for vegetables and fruits (Kruger et al., 1998) show that several wild vegetables are richer sources of various micronutrients than conventional green, leafy vegetables. Table 2 shows a comparison between the nutrient values, per $100 \mathrm{~g}$, for cooked imifino, spinach (Swiss chard) and cabbage. The imifino values were calculated using an average of amabumbe leaves, amaranth leaves, cowpea leaves, pumpkin leaves and sweet potato leaves. Inclusion of the latter types of leaves in the calculation is valid in terms of the actual definition of imifino given above. Values for the individual types of leaves listed, are also shown. In addition values for indigenous and commercially available starchy vegetables, squash/ pumpkin and legumes are shown in Table 3. It can be seen from these tables that indigenous vegetables are good sources of a number of nutrients. When looking at green leafy vegetables, this is true for calcium, iron, vitamin A, folate, Vitamin C and thiamine. In the starchy vegetables category, the amadumbe is equal to or better in almost all the nutrients than potato and sweet potato.

Based on several factors, including nutrient content, accessibility, affordability, acceptance and current use, a number of authors have suggested that the use of indigenous crops in the South African diet should increase (Modi et al., 2006; Nesamvuni et al., 2001). Nesamvuni et al. (2001), based on an analysis of the use and the nutrient composition of wild green leafy vegetables in the districts of Thoyandou, Mutale, Dzanani and Vuwani in the Limpopo Province of South Africa suggested that health educators should promote their consumption in order to increase micronutrient intakes. Modi et al. (2006) in a study in Ezigeni, KwaZulu-Natal, South Africa on general knowledge and availability of wild leafy vegetables showed that inter alia wild green leafy vegetables were available in early spring, when conventional crops were less abundant. This is supported by Chadha and Oluoch (2002) who advocate the production and use of indigenous vegetables to alleviate nutrition deficiencies during the off-season. However as the plants are harvested while growing in their wild state and not farmed in the conventional manner, yields may be low and consequently nutrient contribution to the diet may be low (Chadha and Oluoch 2002). This may be compounded by the fact that women are usually the only 
TABLE 2

Comparison of nutrient composition per $100 \mathrm{~g}$ of cooked green leafy vegetables (after Kruger et al., 1998)

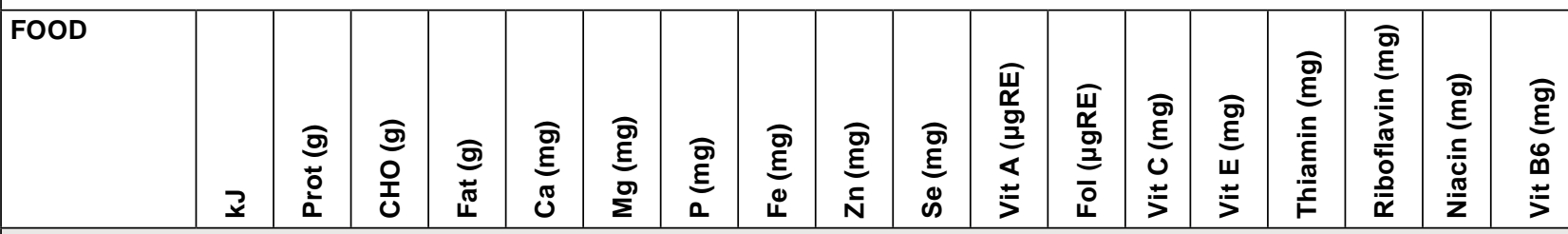

COOKED LEAVES

\begin{tabular}{|l|c|c|c|c|c|c|c|c|c|c|c|c|c|c|c|c|c|c|}
\hline Imifino* $^{*}$ & 141 & 2.8 & 2.2 & 0.3 & 106 & 43 & 55 & 2.5 & 0.38 & 0.9 & 253 & 69 & 18 & 1.13 & 0.21 & 0.21 & 1 & 0.145 \\
\hline Amabumbe & 129 & 2.7 & 2 & 0.4 & 86 & 20 & 27 & 1.2 & 0.21 & 1 & 424 & 48 & 36 & 1.1 & 0.14 & 0.38 & 1.3 & 0.072 \\
\hline Amaranth & 111 & 1.9 & 1.2 & 0.2 & 187 & 37 & 38 & 4.6 & 0.81 & 0.3 & 399 & 5 & 1 & 0.26 & tr & 0.04 & 0.3 & 0.05 \\
\hline Cowpea & 178 & 4.5 & 1.5 & 0.4 & 188 & 60 & 72 & 2.7 & 0.4 & 1.7 & 99 & 141 & 50 & 2.36 & 0.49 & 0.24 & 1.6 & 0.246 \\
\hline Pumpkin & 111 & 2.7 & 0.7 & 0.2 & 43 & 38 & 79 & 3.2 & 0.2 & 0 & 249 & 25 & 1 & 0.96 & 0.07 & 0.14 & 0.9 & 0.196 \\
\hline Sweet potato & 174 & 2.3 & 5.4 & 0.02 & 24 & 61 & 60 & 0.6 & 0.26 & 1.3 & 92 & 124 & 2 & 0.96 & 0.11 & 0.27 & 1 & 0.16 \\
\hline Spinach & 115 & 2.3 & 2.2 & 0.02 & 136 & 59 & 27 & 1.3 & 0.56 & 1 & 168 & 23 & 2 & 0.23 & 0.08 & 0.1 & 0.4 & 0.162 \\
\hline Cabbage & 104 & 1 & 3.2 & tr & 29 & 9 & 24 & 0.4 & 0.17 & 0.6 & 2 & 11 & 20 & 0.2 & 0.02 & 0.01 & 0.2 & 0.05 \\
\hline
\end{tabular}

*Imifino = average from amabumbe leaves, amaranth leaves, cowpea leaves, pumpkin leaves and sweet potato leaves

\begin{tabular}{|c|c|c|c|c|c|c|c|c|c|c|c|c|c|c|c|c|c|c|}
\hline \multicolumn{19}{|c|}{$\begin{array}{l}\text { TABLE } 3 \\
\text { Comparison of nutrient composition per } 100 \mathrm{~g} \text { of cooked starchy vegetables, squashes and legumes } \\
\text { (after Kruger et al., 1998) }\end{array}$} \\
\hline FOOD & $\underline{7}$ & $\begin{array}{l}\text { 후 } \\
\text { 훙 } \\
\overline{0}\end{array}$ & $\begin{array}{l}\text { 오 } \\
\text { 운 } \\
\text { 닌 }\end{array}$ & 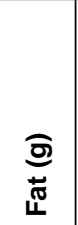 & $\underset{\widetilde{\Xi}}{\stackrel{\widehat{\Xi}}{\overparen{J}}}$ & $\begin{array}{l}\widehat{\widehat{D}} \\
\stackrel{\Xi}{ } \\
\stackrel{D}{\Sigma}\end{array}$ & 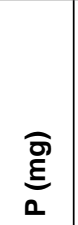 & 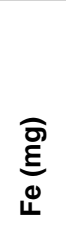 & $\begin{array}{l}\stackrel{D}{\Xi} \\
\stackrel{\Sigma}{N}\end{array}$ & 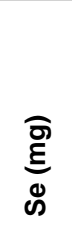 & 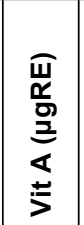 & 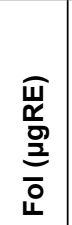 & 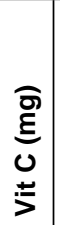 & 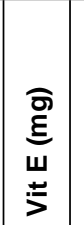 & 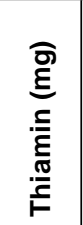 & 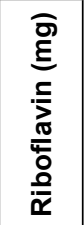 & 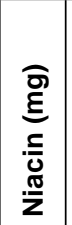 & 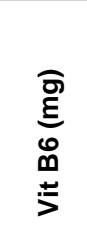 \\
\hline \multicolumn{19}{|l|}{ STARCHY VEGETABLES } \\
\hline Amabumbe/taro & 600 & 0.5 & 29.5 & 0.1 & 18 & 30 & 76 & 0.7 & 0.27 & 0.3 & 0 & 19 & 5 & 0.44 & \begin{tabular}{|l|}
0.11 \\
\end{tabular} & 0.03 & 0.5 & 0.331 \\
\hline Potato & 318 & 1.5 & 15.5 & 0.1 & 6 & 12 & 38 & 0.6 & 0.26 & 0.3 & $\operatorname{tr}$ & 2 & 20 & 0.06 & 0.12 & 0.01 & 1.2 & 0.19 \\
\hline Sweet potato & 311 & 1 & 15.1 & 0.1 & 9 & 13 & 22 & 0.3 & 0.12 & 0.5 & 3 & 6 & 7 & \begin{tabular}{|l|l|}
0.22 \\
\end{tabular} & 0.05 & 0.01 & 0.5 & 0.07 \\
\hline \multicolumn{19}{|l|}{ SQUASHES } \\
\hline Calabash (white) & 120 & 0.6 & 3.7 & 0.02 & 24 & 11 & 13 & 0.3 & 0.7 & 3.2 & & 4 & 4 & & 0.03 & 0.02 & 0.4 & 0.038 \\
\hline Gem squash & 97 & 0.5 & 3.5 & 0.1 & 16 & 22 & 21 & 0.3 & 0.25 & & & 6 & 7 & 0.17 & 0.03 & 0.01 & 1 & 0.07 \\
\hline Butternut & 235 & 1.5 & 10.2 & 0.1 & 16 & 18 & 43 & 0.3 & 0.29 & 0.5 & 332 & 8 & 4 & 1.35 & 0.05 & 0.02 & 1.4 & 0.09 \\
\hline Pumpkin & 92 & 0.7 & 2.9 & 0.1 & 11 & 8 & 17 & 0.3 & 0.12 & 0.1 & 213 & 3 & 5 & \begin{tabular}{|l|l}
0.7 \\
\end{tabular} & 0.02 & 0.01 & 0.4 & 0.06 \\
\hline \multicolumn{19}{|l|}{ LEGUMES } \\
\hline Cowpea/blackeye beans* & 494 & 8.8 & 19.9 & 0.7 & 21 & 45 & 140 & 1.9 & 1.1 & 3 & 0.171 & 210 & $\operatorname{tr}$ & $\mathrm{N}$ & 0.19 & 0.05 & 0.5 & 0.1 \\
\hline Sugarbeans & 585 & 7.1 & 19.5 & 0.6 & 32 & 55 & 122 & 2.1 & 1.06 & & 0 & 140 & 1 & 0.14 & 0.12 & 0.04 & 0.7 & 0.164 \\
\hline White kidney beans & 482 & 7.8 & 13.7 & 0.4 & 17 & 43 & 111 & 2.4 & 0.95 & & 0 & 83 & 0 & -1 & 0.16 & 0.06 & 0.4 & 0.161 \\
\hline Lentils, split, cooked & 487 & 9 & 14.6 & 0.4 & 19 & 36 & 180 & 3.3 & 1.27 & & 1 & 181 & 2 & - & 0.17 & 0.07 & 1.1 & 0.178 \\
\hline \multicolumn{19}{|c|}{$\begin{array}{l}\text { * Reference: Holland et al., } 1991 . \text { McCance and Widdowson's The Composition of Foods } \\
\text { tr }=\text { nutrient present in trace amount } \\
N=\text { nutrient present in significant quantities but there is no reliable information on the amount } \\
\text { Empty cell = missing data }\end{array}$} \\
\hline
\end{tabular}

family members who play a role in the collection or harvesting and preparation of the wild leafy vegetables (Modi et al., 2006; Nesamvuni et al., 2001). A further area of concern is that Modi et al. (2006) also showed lower levels of knowledge and esteem regarding these plants in younger age groups within the community and emphasized the importance of education so that this knowledge is not lost.

A study conducted by Nesamvuni et al. (2001) on women in Venda, Limpopo Province, South Africa found that a serving (180-270g) of miroho was consumed once a week. The plants are usually prepared with tomato, onion and/or peanuts, which increase energy, protein, folate, vitamin $\mathrm{C}$ and calcium intake (Jansen van Rensburg et al., 2004; Nesamvuni et al., 2001).
Studies conducted in Bangladesh showed an improvement in Vitamin A status in children aged 2 to 6 years who consumed green leafy vegetables with added fat (Takyi, 1999).

The bioavailability of the nutrients in these indigenous plants is also an important consideration. Green, leafy vegetables contain both phytates and oxalates, which decrease the absorption of calcium and iron. Iron absorption will however be enhanced if the vegetable is a good source of vitamin $C$ or is eaten with a good source of Vitamin C, e.g. an orange (Chadha and Oluoch, 2002; Nesamvuni et al., 2001).

Labadarious and Steyn (2001) encouraged the consideration of indigenous vegetables in relation to fulfilling the FBDG 'Eat plenty of vegetables and fruit'. Steyn et al. (2006b), following 
analysis of the data from the 1999 National Food Consumption Survey, show that $9.5 \%$ of the children surveyed consumed wild leaves/spinach. The average portion size was $151.9 \mathrm{~g}$ and the mean per capita intake was $14.5 \mathrm{~g}$. Their study also found that, amongst others, the Food Based Dietary Guidelines 'Enjoy a variety of foods' and 'Eat plenty of vegetables and fruits every day’ were not met (Steyn et al., 2006b). Promoting and increasing the consumption of indigenous vegetables could contribute to more people being able to meet these guidelines and improve their food security and micronutrient intakes and also decrease the risk of obesity and cardiovascular disease.

\section{Conclusions}

The information available on nutritional intakes and status in South Africa shows that we face a double burden of nutritional problems (both under- and over-nutrition). Food insecurity related to poverty, low intakes of fruit and vegetables, and low intakes of energy and micronutrients, and in contrast, obesity, are widespread. The low fruit and vegetable intakes are a problem in relation to both inadequate nutrient intakes and chronic diseases of lifestyle. To counteract this, the South African FBDG promote fruit and vegetable consumption. However, the amounts of fruits and vegetables available and consumed in South Africa are low compared to WHO recommendations. Although most food eaten in South African households is bought, crop production and livestock production still occurs in a significant minority of households in South Africa. Livestock production is mainly in the rural areas, but crop production occurs in urban as well as rural areas. Analysis of the 1999 NFCS, showed that intakes of several nutrients were higher in households with agricultural production, but in order to achieve adequate production further interventions are needed, particularly in the rural areas.

The intervention by Faber et al. (2002) shows that in order for nutrient intakes of producers to be significantly increased so that adequate intakes are achieved, crops which are rich in micronutrients need to be targeted by agriculturalists, and nutrition education also needs to be provided. The study by Faber et al. (2002) provides an excellent model of an intervention where, even in the context of poverty, nutritional intakes can be increased. It combines nutrition and agricultural expertise, there is good supervision and community involvement, and the crops introduced were rich in the nutrient for which there is a problem. Indigenous crops are good sources of a number of nutrients, grow in more arid areas, grow in seasons when other vegetables are in short supply and therefore should be considered as part of such future interventions. There is already evidence of continued use of indigenous crops in ad hoc studies; however, there is a concern that the knowledge may die out. This short review emphasizes the importance of fruit and vegetables in the diet. An important contribution is needed, and could be made by crops, including indigenous crops to the diet.

\section{References}

BOLAANE L (2006) Nutrient Intakes, Dietary Diversity, Hunger Perceptions and Anthropometry of Children aged 1-3 years in Households Producing Crops and Livestock in South Africa: A Secondary Analysis of National Food Consumption Survey of 1999. M.Sc. Dissertation, Discipline of Dietetics and Human Nutrition, University of KwaZulu-Natal, Pietermaritzburg. 178 pp.

CHADHA ML and OLUOCH MO (2002) Home-based vegetable gardens and other strategies to overcome micronutrient malnutrition in developing countries. Food, Nutrition and Agriculture: FAO 32/2002. 7 pp.
DEPARTMENT OF HEALTH (2004) South African Demographic and Health Survey 2003. Department of Health: Pretoria. 34 pp. URL: http://www.doh.gov.za/docs/index.html (Accessed on 16 April 2007).

FABER M, VENTER SL and BENADE AJS (2002) Increased vitamin A intake in children aged 2-5 years through targeted home-gardens in a rural South African community. Public Health Nutr. 5 (1) 11-16.

FABER M, VAN JAARSVELD PJ and LAUBSCHER R (2007) The contribution of dark-green leafy vegetables to total micronutrient intake of two- to five-year old children in a rural setting. Water $S A$ 33 (3) 407-412.

GERICKE G, LABADARIOS D and NEL JH (2000) Chapter 8: hunger scale questionnaire: a measure of hunger. In: Labadarios D (ed.) The National Food Consumption Survey (NFCS): Children aged 1-9 Years, South Africa, 1999. 218pp. URL: http://www.sahealthinfo. org/nutrition/food8hungerscale.pdf (Accessed on 7 May 2004).

HIRSCHOWITZ R (2002) Earning and spending in South Africa: Selected findings and comparison from the income and expenditure surveys of October 1995 and October 2000. Statistics South Africa: Pretoria. $64 \mathrm{pp}$.

HOLLAND B, WELCH AA, UNWIN ID, BUSS DH, PAUL AA and SOUTHGATE DAT (1991) In: McCance and Widdowson's (eds.) The Composition of Foods ( $5^{\text {th }}$ edn.). Royal Society of Chemistry and Ministry of Agriculture, Fisheries and Food: City. 462 pp.

JANSEN VAN RENSBURG WS, VENTER SL, NETSHILUVHI TR, VAN DEN HEEVER E, VORSTER HJ and DE RONDE JA (2004) Role of indigenous leafy vegetables in combating hunger and malnutrition. S. Afr. J. Bot. 70 (1) 52-59.

KELLER I (2005) From the WHO/FAO Framework on Fruit and Vegetable Promotion to a national plan of action. Presentation at the International Workshop on the Consumption of Fruit and Vegetables for Health and Nutrition, 20 September 2005, Durban.

KRUGER M, SAYED N, LANGENHOVEN M and HOLING F (1998) Composition of South African Foods: Vegetables and Fruit. Supplement to the MRC Food Composition Tables 1991. Tygerberg: Medical Research Council. 160 pp.

LABADARIOS D and STEYN NP (2001) South African food-based dietary guidelines - guidelines for whom? S. Afr. J. Clin. Nutr. 14 (1) 5-6.

LABADARIOS D, STEYN NP, MAUNDER E, MACINTYRE U, GERICKE G, SWART R, HUSKISSON J, DANNHAUSER A, VORSTER HH, NESAMVUNI AE and NEL JH (2005). The National Food Consumption Survey (NFCS): South Africa, 1999. Public Health Nutr. 8 (5) 533-543.

LABADARIOS D and VAN MIDDELKOOP A (EDS.) (1995) The South African Vitamin A Consultative Group (SAVACG). Children aged 6 to 71 months in South Africa, 1994: Their anthropometric, vitamin A, iron and immunisation coverage status. Isando: SAVACG. 157pp. URL: http://www.sahealthinfo.org/nutrition/vitamina.htm (Accessed on 23 April 2007).

LOVE P and SAYED N (2001) Eat plenty of vegetables and fruits everyday. S. Afr. J. Clin. Nutr. (Supplement) 14 (3) S24-S32.

MACINTYRE U and LABADARIOS D (2000) Chapter 6: Dietary intake: Quantitative Food frequency method. In: Labadarios D (ed). The National Food Consumption Survey (NFCS): Children aged 1 - 9 years, South Africa, 1999. Department of Health: Pretoria. 176pp. URL: http://www.sahealthinfo.org/nutrition/foodconsumption.htm (Accessed on 7 March 2005).

MAUNDER E and LABADARIOS D (2000) Chapter 7: The food procurement and household inventory method. In: Labadarios D (ed.) The National Food Consumption Survey (NFCS): Children aged 1 - 9 years, South Africa, 1999. Department of Health: Pretoria. 143pp. URL: http://www.sahealthinfo.org/nutrition/foodconsumption.htm (Accessed on 7 March 2005).

MAUNDER EMW, MATJI J and HLATSHWAYO-MOLEA T (2001). Enjoy a variety of foods - difficult but necessary in developing countries. S. Afr. J. Clin. Nutr. (Supplement) 14 (3) S3-S6.

MODI M, MODI AT and HENDRIKS S (2006) Potential role for wild vegetables in household food security: a preliminary case study in KwaZulu-Natal. Afr. J. Food, Agriculture, Nutrition and Development (AJFAND online) 6 (1) 2-13. 
NESAMVUNI C, STEYN NP and POTGIETER MJ (2001) Nutritional value of wild, leafy plants consumed by the Vhavenda. S. Afr. J. Sci. 97 51-54.

ROSE D, BOURNE L and BRADSHAW D (2002) Food and nutrient availability in South African households. Development of a nationally representative database. Technical Report. Health and Development Research Group and the Burden of Disease Unit. Cape Town: South African Medical Research Council. 41 pp.

ROSE D and CHARLTON KE (2002) Quantitative indicators from a food expenditure survey can be used to target the food insecure in South Africa. J. Nutr. 132 3235-3242.

SCHMIDT MI and VORSTER HH (1995) The effect of communal vegetable gardens on nutritional status. Dev. South. Afr. 12 (5) 713724.

STEYN NP, BRADSHAW D, NORMAN R, JOUBERT JD, SCHNEIDER M and STEYN K (2006a) Dietary changes and the Health Transition in South Africa: Implication for Health Policy. Cape Town: South African Medical Research Council. 47 pp.

STEYN NP and LABADAROIS D (2000) Chapter 5: Dietary intakethe 24-hour recall. The 1999 National Food Consumption Survey. 92 pp. URL: http://www.sahealthinfo.org/nutrition/food5dietaryintake.pdf (Accessed on 21 April 2006).

STEYN NP, LABADARIOS D, MAUNDER E, NEL J and LOMBARD C (Directors of the National Food Consumption Survey) (2005) Secondary anthropometric data analysis of the National Food
Consumption Survey in South Africa: the double burden. Nutr. 21 (1) 4-13.

STEYN NP, MAUNDER EMW, LABADARIOS D and NEL JH (2006b) Foods and beverages that make significant contributions to macro- and micronutrient intakes of children in South Africa - do they meet the food-based dietary guidelines? S. Afr. J. Clin. Nutr. 19 (2) 66-76.

STEYN NP, NEL JH and CASEY A (2003) Secondary data analyses of dietary surveys undertaken in South Africa to determine usual food consumption of the population. Public Health Nutr. 6 (7) 631-644.

TAKYI EEK (1999) Children's Consumption of Dark Green, Leafy Vegetables with Added Fat Enhances Serum Retinol. J. Nutr. 129 1549-1554.

VAN DER WALT AM, MOSSANDA KSA, JIVAN SD, SWART WJ and BEZUIDENHOUT CC (2005) Indigenous African food plants: Vehicles of disease or sources of protection? Indilinga: Afr. J. Indigenous Knowledge Systems (IAJIKS) 4 (1) 270-279.

VORSTER HH, LOVE P and BROWNE C (2001) Development of Food-Based Dietary Guidelines for South Africa - the Process. S. Afr. J. Clin. Nutr. (Supplement) 14 (3) S3-S6.

WEBB NL (2000) Food-gardens and nutrition: Three Southern African cases studies. J. Family Ecol. Consumer Sci. 28 61-67.

WHO (2003) Diet, Nutrition and the Prevention of Chronic Diseases. Report of a joint WHO/FAO expert consultation. WHO Technical Report Series 916. World Health Organisation: Geneva. 149 pp. 